\title{
Synthesis, Crystal Structure, and Spectra Properties of the Cadmium (II) Complex with Bis $(\boldsymbol{N}$-allylbenzimidazol-2-ylmethyl)benzylamine
}

\author{
Huilu Wu, Jingkun Yuan, Ying Bai, Fan Kou, Fei Jia, and Bin Liu \\ School of Chemical and Biological Engineering, Lanzhou Jiaotong University, Lanzhou 730070, China \\ Correspondence should be addressed to Huilu Wu, wuhuilu@163.com
}

Received 27 May 2011; Revised 18 July 2011; Accepted 18 July 2011

Academic Editor: Giovanni Natile

Copyright () 2011 Huilu Wu et al. This is an open access article distributed under the Creative Commons Attribution License, which permits unrestricted use, distribution, and reproduction in any medium, provided the original work is properly cited.

\begin{abstract}
A novel complex of cadmium (II) picrate (pic) with V-shaped ligand bis( $N$-allylbenzimidazol-2-ylmethyl)benzylamine (babb), with composition $\left[\mathrm{Cd}(\mathrm{babb})_{2}\right](\mathrm{pic})_{2}$, was synthesized and characterized by elemental analyses and electrical conductivity, IR, and UV/visible spectra. The crystal structure of the complex has been determined by the single-crystal X-ray diffraction. In the complex, the coordination sphere around Cd (II) is distorted octahedral, six nitrogen atoms involved in coordination afforded by two tridentate ligand babb. Moreover, The DNA-binding properties of the ligand babb and Cd (II) complex were investigated by spectrophotometric methods and viscosity measurements, and the results suggest that they bind to DNA via an intercalation binding mode, and the Cd (II) complex shows higher affinity than the ligand.
\end{abstract}

\section{Introduction}

Benzimidazole is a typical heterocyclic ligand with nitrogen as the donor atom. It may mimic the histidine imidazole in coordination aspects and it is a component of biologically important molecules [1]. Due to the privileged structure [2], benzimidazoles and their derivatives have attracted great deal of interests because of their potential application in the area of drugs and pharmaceuticals such as antitumor [3], antiviral [4], anticancer [5], antimicrobial [6], antiprotozoal [7], and anti-inflammatory or analgesic activities [8]. Besides, this type of materials was distinctively studied for their reaction activities and roles as important intermediate in the inorganic and organic synthesis. Binding studies of small molecules to DNA are very important in the development of DNA molecular probes and new therapeutic reagents [9]. Transition metal complexes have attracted considerable attention as oxidation catalysts [10], probes in electrontransfer reactions involving metallo-proteins [11], and intercalators with DNA [12]. The studies about transition metal complexes contribute to further understanding irreplaceable role of transition metal in vivo [13].
In previous papers [14-17], we have investigated the coordinating ability of some kind of benzimidazoles ligands. In this paper, we have prepared and investigated the spectrum properties and crystal structure of the cadmium (II) complex with a novel V-shaped ligand bis $(N$ allylbenzimidazol-2-ylmethyl)benzylamine (babb). Besides, we also conduct the related research on the DNA-binding properties of this compound to investigate the mode of the complex bond to DNA.

\section{Experimental}

2.1. Materials and Instruments. The $\mathrm{C}, \mathrm{H}$, and $\mathrm{N}$ elemental analyses were determined using a Carlo Erba 1106 elemental analyzer. Electrolytic conductance measurements were made with a DDS-307-type conductivity bridge using $3 \times$ $1^{-3} \mathrm{~mol} \mathrm{~L}^{-1}$ solutions in DMF at room temperature. The IR spectra were recorded in the $4000-400 \mathrm{~cm}^{-1}$ region with a Nicolet FT-VERTEX 70 spectrometer using $\mathrm{KBr}$ pellets. Electronic spectra were taken on a Lab-Tech UV Bluestar spectrophotometer. The fluorescence spectra were recorded on an LS-45 spectrofluorophotometer. 
Calf thymus DNA (CT-DNA) and ethidium bromide (EB) were purchased from Sigma. All chemicals used were of analytical grade. All the experiments involving interaction of the ligand and the complexes with CT-DNA were carried out in doubly distilled water buffer containing $5 \mathrm{mM}$ Tris and $50 \mathrm{mM} \mathrm{NaCl}$ and adjusted to $\mathrm{pH} 7.2$ with hydrochloric acid. A solution of CT-DNA gave a ratio of UV absorbance at 260 and $280 \mathrm{~nm}$ of about $1.8-1.9$, indicating that the CT-DNA was sufficiently free of protein [18]. The CT-DNA concentration per nucleotide was determined spectrophotometrically by employing an extinction coefficient of $6600 \mathrm{M}^{-1} \mathrm{~cm}^{-1}$ at $260 \mathrm{~nm}$ [19].

Absorption titration experiments were performed with fixed concentrations of the complex, while gradually increasing the concentration of CT-DNA. To obtain the absorption spectra, the required amount of CT-DNA was added to both compound solution and the reference solution to eliminate the absorbance of CT-DNA itself. From the absorption titration data, the binding constant $\left(K_{b}\right)$ was determined using the equation in [20]

$$
\frac{[\mathrm{DNA}]}{\varepsilon_{a}-\varepsilon_{f}}=\frac{[\mathrm{DNA}]}{\varepsilon_{b}-\varepsilon_{f}}+\frac{1}{K_{b}\left(\varepsilon_{b}-\varepsilon_{f}\right)},
$$

where [DNA] is the concentration of CT-DNA in base pairs, $\varepsilon_{a}$ corresponds to the extinction coefficient observed ( $\left.A_{\mathrm{obsd}} /[\mathrm{M}]\right), \varepsilon_{f}$ corresponds to the extinction coefficient of the free compound $\varepsilon_{b}$, is the extinction coefficient of the compound when fully bound to CT-DNA, and $K_{b}$ is the intrinsic binding constant. The ratio of slope to intercept in the plot of [DNA] $/\left(\varepsilon_{a}-\varepsilon_{f}\right)$ versus [DNA] gave the value of $K_{b}$.

EB emits intense fluorescence in the presence of CTDNA, due to its strong intercalation between the adjacent CT-DNA base pairs. It was previously reported that the enhanced fluorescence can be quenched by the addition of a second molecule $[21,22]$. The extent of fluorescence quenching of EB bound to CT-DNA can be used to determine the extent of binding between the second molecule and CTDNA. The competitive binding experiments were carried out in the buffer by keeping $[\mathrm{DNA}] /[\mathrm{EB}]=1$ and varying the concentrations of the compounds. The fluorescence spectra of $\mathrm{EB}$ were measured using an excitation wavelength of $520 \mathrm{~nm}$, and the emission range was set between 550 and $750 \mathrm{~nm}$. The spectra were analyzed according to the classical Stern-Volmer equation in [23]

$$
\frac{I_{0}}{I}=1+K_{\mathrm{SV}}[Q]
$$

where $I_{0}$ and $I$ are the fluorescence intensities at $599 \mathrm{~nm}$ in the absence and presence of the quencher, respectively, $K_{\mathrm{SV}}$ is the linear Stern-Volmer quenching constant, and $[Q]$ is the concentration of the quencher. In these experiments, [CT$\mathrm{DNA}]=2.5 \times 10^{-3} \mathrm{~mol} / \mathrm{L},[\mathrm{EB}]=2.2 \times 10^{-3} \mathrm{~mol} / \mathrm{L}$.

Viscosity experiments were conducted on an Ubbelodhe viscometer, immersed in a water bath maintained at 25.0 $\pm 0.1^{\circ} \mathrm{C}$. Titrations were performed for the complexes $(3-$ $35 \mu \mathrm{M})$, and each compound was introduced into CTDNA solution $(50 \mu \mathrm{M})$ present in the viscometer. Data were
TABLE 1: Crystallographic data and data collection parameters for $\left[\mathrm{Cd}(\mathrm{babb})_{2}\right](\text { pic })_{2}$.

\begin{tabular}{ll}
\hline Complex & {$\left[\mathrm{Cd}(\mathrm{babb})_{2}\right](\text { pic })_{2}$} \\
\hline Molecular formula & $\mathrm{C}_{70} \mathrm{H}_{62} \mathrm{CdN}_{16} \mathrm{O}_{14}$ \\
Molecular weight & 1463.76 \\
Crystal system & Triclinic \\
Space group & $\mathrm{P}-1$ \\
$\mathrm{a}(\AA)$ & $13.903(4)$ \\
$\mathrm{b}(\AA)$ & $14.146(4)$ \\
$\mathrm{c}(\AA)$ & $19.330(5)$ \\
$\alpha\left(^{\circ}\right)$ & $90.595(3)$ \\
$\beta\left(^{\circ}\right)$ & $110.890(3)$ \\
$\gamma\left(^{\circ}\right)$ & $106.325(3)$ \\
$V\left(^{\circ} \AA^{3}\right)$ & $3382.5(16)$ \\
$Z$ & 2 \\
$\rho_{\text {cald }}\left(\right.$ mg $\left.{ }^{-3}\right)$ & 1.437 \\
$F(000)$ & 1508 \\
Crystal size (mm) & $0.40 \times 0.38 \times 0.30$ \\
$\theta$ range for data collection $\left(^{\circ}\right)$ & 2.25 to 25.00 \\
$h / k / l($ max, min) & $-16,16 /-15,16 /-22,22$ \\
Reflections collected & 20103 \\
Independent reflections & $11730[R($ int $)=0.0253]$ \\
Completeness to theta $=25.00$ & $98.4 \%$ \\
Refinement method & Full-matrix least- \\
Data/restraints/parameters & squares on $F^{2}$ \\
Goodness-of-fit on $F^{2}$ & $11730 / 49 / 910$ \\
Final $R 1, w R 2$ indices $[I>2 \sigma(I)]$ & 1.008 \\
$R 1, w R 2$ indices $($ all data $)$ & $0.0473,0.1117$ \\
Largest differences peak and hole & $0.0682,0.1249$ \\
$\left(\mathrm{e} \AA^{-3}\right)$ & 0.986 and -0.537 \\
\hline
\end{tabular}

presented as $\left(\eta / \eta_{0}\right)^{1 / 3}$ versus the ratio of the concentration of the compound to CT-DNA, where $\eta$ is the viscosity of CTDNA in the presence of the compound and $\eta_{0}$ is the viscosity of CT-DNA alone. Viscosity values were calculated from the observed flow time of CT-DNA-containing solutions corrected from the flow time of buffer alone $\left(t_{0}\right), \eta=\left(t-t_{0}\right)$ [24].

\subsection{Compound Preparation}

2.2.1. Preparation of the Bis(N-allylbenzimidazol-2-ylmethyl) benzylamine (babb). The precursor-bis(2-benzimidazol-2ylmethyl)benzylamine (bbb) was synthesized following a slight modification of the procedure [25]. $7.34 \mathrm{~g}$ (20mmol) bbb with $1.56 \mathrm{~g} \mathrm{(} 40 \mathrm{mmol}$ ) potassium in $150 \mathrm{~mL}$ tetrahydrofuran followed by adding $4.84 \mathrm{~g}(40 \mathrm{mmol})$ allyl bromide.

The resulting solution was concentrated and recrystallized from ethanol and the pale yellow block crystals were obtained [26]. Yield: 5.46 g (61\%); m.p.: $113-115^{\circ} \mathrm{C}$. Anal. calcd. for $\mathrm{C}_{29} \mathrm{H}_{29} \mathrm{~N}_{5}$ : C, 77.82; H, 6.53; N, 15.65. Found: C, 
TABLe 2: Selected atomic distances $(\AA)$ and bond angles $\left(^{\circ}\right)$ for the complex.

\begin{tabular}{lccr}
\hline Bond distances & & & \\
\hline $\mathrm{Cd}(1)-\mathrm{N}(15)$ & $2.248(3)$ & $\mathrm{Cd}(1)-\mathrm{N}(13)$ & $2.319(3)$ \\
$\mathrm{Cd}(1)-\mathrm{N}(11)$ & $2.281(3)$ & $\mathrm{Cd}(1)-\mathrm{N}(7)$ & $2.556(3)$ \\
$\mathrm{Cd}(1)-\mathrm{N}(9)$ & $2.307(3)$ & $\mathrm{Cd}(1)-\mathrm{N}(12)$ & $2.673(3)$ \\
\hline Bond angles & & & $70.12(10)$ \\
\hline $\mathrm{N}(15)-\mathrm{Cd}(1)-\mathrm{N}(11)$ & $109.41(11)$ & $\mathrm{N}(9)-\mathrm{Cd}(1)-\mathrm{N}(7)$ & $92.25(11)$ \\
$\mathrm{N}(15)-\mathrm{Cd}(1)-\mathrm{N}(9)$ & $96.74(11)$ & $\mathrm{N}(13)-\mathrm{Cd}(1)-\mathrm{N}(7)$ & $70.80(11)$ \\
$\mathrm{N}(11)-\mathrm{Cd}(1)-\mathrm{N}(9)$ & $106.65(11)$ & $\mathrm{N}(11)-\mathrm{Cd}(1)-\mathrm{N}(12)$ & $165.10(10)$ \\
$\mathrm{N}(15)-\mathrm{Cd}(1)-\mathrm{N}(13)$ & $100.72(12)$ & $\mathrm{N}(9)-\mathrm{Cd}(1)-\mathrm{N}(12)$ & $87.96(10)$ \\
$\mathrm{N}(11)-\mathrm{Cd}(1)-\mathrm{N}(13)$ & $98.24(11)$ & $\mathrm{N}(13)-\mathrm{Cd}(1)-\mathrm{N}(12)$ & $67.50(10)$ \\
$\mathrm{N}(9)-\mathrm{Cd}(1)-\mathrm{N}(13)$ & $\mathrm{N}(7)-\mathrm{Cd}(1)-\mathrm{N}(12)$ & $111.11(9)$ \\
$\mathrm{N}(15)-\mathrm{Cd}(1)-\mathrm{N}(7)$ & $142.69(11)$ & & \\
$\mathrm{N}(11)-\mathrm{Cd}(1)-\mathrm{N}(7)$ & $166.37(10)$ & &
\end{tabular}

78.02; $\mathrm{H}, 6.35 ; \mathrm{N}, 15.71 \%$. IR data $\left(\mathrm{KBr} \nu / \mathrm{cm}^{-1}\right): 737\left(\nu_{\mathrm{o}-\mathrm{Ar}}\right)$; $1265\left(\nu_{\mathrm{C}-\mathrm{N}}\right) ; 1461\left(\nu_{\mathrm{C}=\mathrm{N}}\right), 1614\left(\nu_{\mathrm{C}=\mathrm{C}}\right)$.

2.2.2. Preparation of $\left[\mathrm{Cd}(\mathrm{babb})_{2}\right](\mathrm{pic})_{2}$. To a stirred solution of babb $(223.5 \mathrm{mg}, 0.5 \mathrm{mmol})$ in hot EtOH $(10 \mathrm{~mL})$ was added cadmium (II) picrate $(142.15 \mathrm{mg}, 0.25 \mathrm{mmol})$ in EtOH $(5 \mathrm{~mL})$. A yellow crystalline product which formed rapidly was filtered off, washed with $\mathrm{EtOH}$ and absolute $\mathrm{Et}_{2} \mathrm{O}$, and dried in vacuo. The dried precipitate was dissolved in acetonitrile resulting in a yellow solution that was allowed to evaporate at room temperature. Pale yellow crystals suitable for X-ray diffraction studies were obtained after two weeks. Yield: $269 \mathrm{mg}(67 \%)$. Anal. calcd. for $\mathrm{C}_{70} \mathrm{H}_{62} \mathrm{CdN}_{16} \mathrm{O}_{14}$ (MW 1463.76): C, 69.14; H, 5.80; N, 13.90 . Found: C, 69.33; H, 5.71; N, 13.79\%. $\Lambda_{\mathrm{M}}$ (DMF, $\left.297 \mathrm{~K}\right)$ : $135.67 \mathrm{~S} \mathrm{~cm}^{2} \mathrm{~mol}^{-1}$. IR data $\left(\mathrm{KBr} v / \mathrm{cm}^{-1}\right): 746\left(\nu_{\mathrm{o}-\mathrm{Ar}}\right) ; 1288$ $\left(\nu_{\mathrm{C}-\mathrm{N}}\right) ; 1479\left(\nu_{\mathrm{C}=\mathrm{N}}\right), 1633\left(\nu_{\mathrm{C}=\mathrm{C}}\right)$.

2.2.3. X-Ray Structure Determination. A suitable single crystal was mounted on a glass fiber and the intensity data were collected on a Bruker APEX-II CCD diffractometer with graphite-monochromated Mo- $K_{\alpha}$ radiation $(\lambda=0.71073 \AA)$ at $153 \mathrm{~K}$. Date reduction and cell refinement were performed using SAINT programs [27]. The absorption corrections were carried out by the empirical method. The structure was solved by direct methods and refined by full-matrix least-squares against $F^{2}$ of data using SHELXTL software [28]. All $\mathrm{H}$ atoms were found in difference electron density maps and were subsequently refined in a riding-model approximation with $\mathrm{C}-\mathrm{H}$ distances ranging from 0.93 to $0.97 \AA$ and $\mathrm{U}_{\text {iso }}(\mathrm{H})=1.2 \mathrm{U}_{\mathrm{eq}}(\mathrm{C})$. Basic crystal data, description of the diffraction experiment, and details of the structure refinement are given in Table 1. Selected bond distances and angles are presented in Table 2.

\section{Results and Discussion}

The cadmium complex is soluble in DMF, DMSO, and acetonitrile, but insoluble in methanolethanol and other organic solvents. The elemental analyses show that the composition is $\left[\mathrm{Cd}(\mathrm{babb})_{2}\right](\mathrm{pic})_{2}$, which is the same with the theoretical ratio. A composition of molar conductance value shows the $1: 2$ electrolytes of the complex in DMF with those previously reported in the literature [29].

3.1. Crystal Structure. The crystal structure of complex consists of discrete $\left[\mathrm{Cd}(\mathrm{babb})_{2}\right]^{2+}$ cation and two picrate anions. The ORTEP structure of $\left[\mathrm{Cd}(\mathrm{babb})_{2}\right]^{2+}$ with atomnumberings is shown in Figure 1.

The cadmium ion is six-coordinate with an N6 ligand set. The ligand babb acts as a tridentate $\mathrm{N}$-donor. The coordination geometry of the Cd (II) may be best described as distorted octahedral with $(\mathrm{N} 9, \mathrm{~N} 11, \mathrm{~N} 12, \mathrm{~N} 13)$ from an equatorial plane. In the four selected nitrogen atoms, the maximum deviation distance (N13) from the least square plane calculated from the four $\mathrm{N}$ atoms is 0.321 (3) $\AA$, which indicated four selected coordination nitrogen atoms almost in a plane. The bond angle of the two atoms (N7, N15) in axial positions is $166.37(10)^{\circ} \AA$, and the distances deviation from the plane are $2.100 \AA$ and $2.395 \AA$, respectively. Therefore, compared with a regular octahedron, it reflects a relatively distorted coordination octahedron around Cd (II) [30].

3.2. IR and UV-Visible Spectra. In the free ligand, a strong band is found around $1265 \mathrm{~cm}^{-1}$ along with a medium band at $1461 \mathrm{~cm}^{-1}$. By analogy with the assigned bands of imidazole, the former is attributed to $v_{\mathrm{C}-\mathrm{N}}$, while the other one is $v_{\mathrm{C}=\mathrm{N}}$ [31-33]. The location of the two bands occurred slightly migration in the complex, which implies direct coordination of all four imine nitrogen atoms to $\mathrm{Cd}$ (II) [34]. Information regarding the possible bonding modes of the picrate and benzimidazole rings also can be obtained from the IR spectra [35].

DMF solutions of the ligand babb and the complex show, as expected, that the UV bands of babb $(279 \mathrm{~nm})$ are only marginally blue-shifted in the complex, which shows clear evidence of $\mathrm{C}=\mathrm{N}$ coordination to cadmium. The absorption bands are assigned to $\pi \rightarrow \pi^{*}$ (imidazole) [36]. This conclusion is confirmed by the result of the crystal structure analysis. 


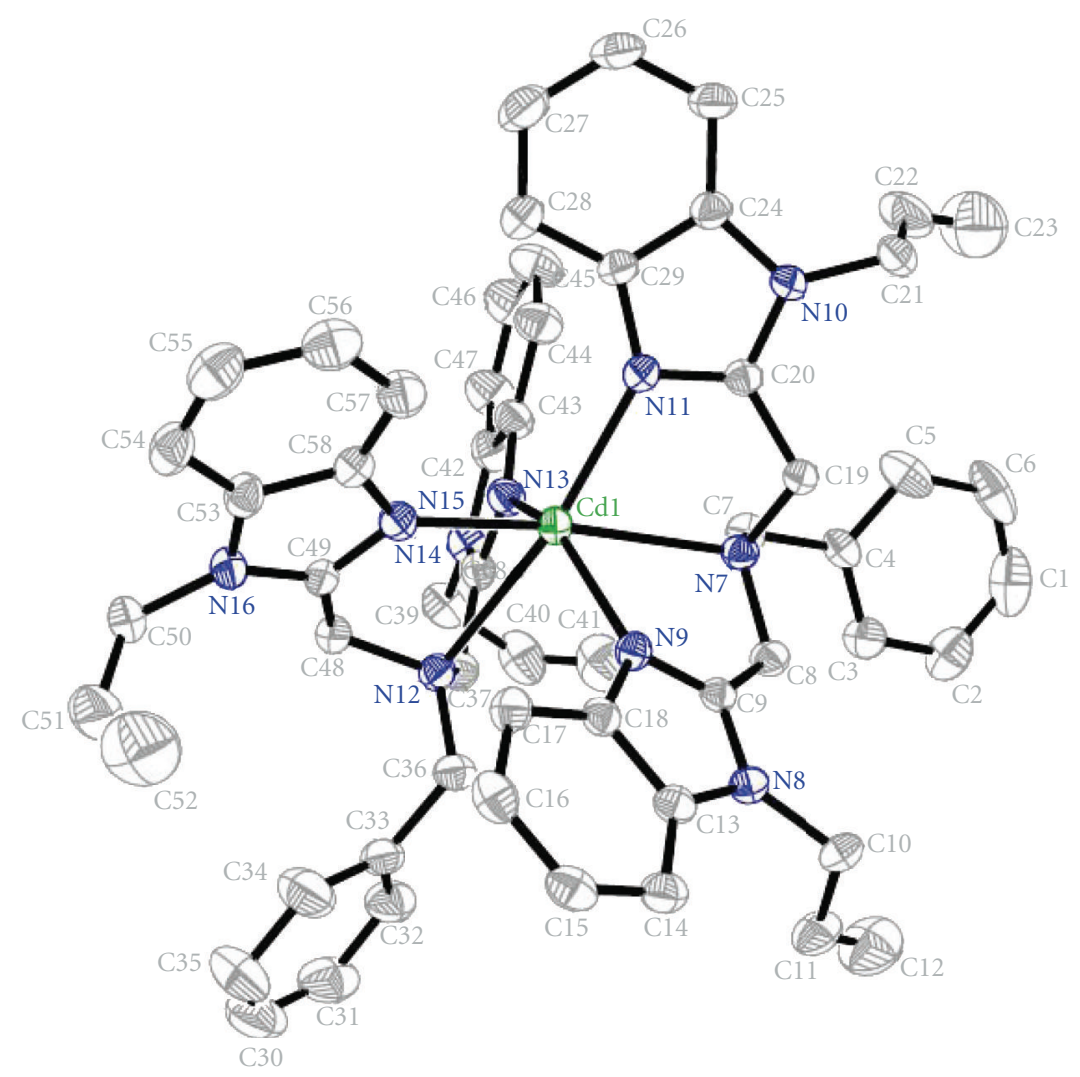

FIGURE 1: Molecular structure and atom-numberings of $\left[\mathrm{Cd}(\mathrm{babb})_{2}\right]^{2+}$ with hydrogen atoms omitted for clarity.

3.3. Absorption Titration. The absorption titration experiment was carried out to investigate the binding affinity of the complexes with CT-DNA. A complex bound to DNA through intercalation is characterized by hypochromism in absorbance and red shift in wavelength, due to the intercalation mode involving a strong stacking interaction between the aromatic chromophore and the DNA base pairs [37]. A certain amount of hypochromism is commonly consistent with the strength of the intercalative interaction [38-40]. The intrinsic binding constants $K_{b}$ of the complexes with DNA were obtained by monitoring the changes in absorbance at $270-280 \mathrm{~nm}$ for the complex with increasing concentration of DNA. The absorption spectral titration of the complex binding to DNA was performed by increasing a certain amount of DNA $(5 \mu \mathrm{L})$ to complex in Tris- $\mathrm{HCl}$ buffer. The sample solution was scanned in the range of 200$500 \mathrm{~nm}$. The constant $\left(K_{b}\right)$ was obtained by the following equation [20]: [DNA] $/\left(\varepsilon_{a}-\varepsilon_{f}\right)=[\mathrm{DNA}] /\left(\varepsilon_{b}-\varepsilon_{f}\right)+1 / K_{b}$ $\left(\varepsilon_{b}-\varepsilon_{f}\right)$, apparent absorption coefficient $\varepsilon_{a}, \varepsilon_{f}$, and $\varepsilon_{b}$ correspond to $A_{\mathrm{obsd}} /[\mathrm{M}]$, the extinction coefficient of the free complex and the extinction coefficient of the complex when fully bound to DNA, respectively. In plots of [DNA $] /\left(\varepsilon_{a}-\right.$ $\left.\varepsilon_{f}\right)$ versus $[\mathrm{DNA}], K_{b}$ is given by the ratio of slope to the intercept.

The absorption spectra of the ligand babb and Cd (II) complex in the absence and presence of DNA at different concentrations are given in Figure 2. With increasing DNA concentrations, the hypochromisms are $18.26 \%$ at $275 \mathrm{~nm}$ for babb and $50.29 \%$ at $280 \mathrm{~nm}$ for Cd (II) complex. The $\lambda_{\max }$ for ligand babb and Cd (II) complex increased from 275 to $276 \mathrm{~nm}, 276$ to $278 \mathrm{~nm}$, respectively. The $K_{b}$ values of babb, Cd (II) complex were $2.26 \times 10^{3} \mathrm{M}^{-1}(R=0.98$ for 15 points), $1.46 \times 10^{5} \mathrm{M}^{-1}$ ( $R=0.99$ for 16 points), respectively. The results may be suggested that the ligand babb and Cd (II) complex bind to DNA via the intercalation mode, involving strong $\pi \rightarrow \pi^{*}$ stacking interactions between benzimidazole rings of the compounds and DNA base pairs, and the binding strength of Cd (II) complex is greater than the ligand.

3.4. EB Competitive Experiment. No luminescence was observed for the complex at room temperature in any organic solvent or in the presence of CT-DNA. So the binding of complexes with CT-DNA cannot be directly presented in the emission spectra. Therefore, competitive EB binding studies could be undertaken in order to examine the binding of each complex with DNA. EB (ethidium bromide) is a conjugate planar molecule. Its fluorescence intensity is very weak in solvent, but it is greatly increased when EB is specifically intercalated into the base pairs of doublestranded DNA. In previous studies, the fluorescent light could be quenched by the addition of the complex which can compete with EB to bind with DNA. This is a proof that the complexes intercalate to base pairs of DNA [41]. The SternVolmer quenching constant $K_{\mathrm{SV}}$ is often used to evaluate the 


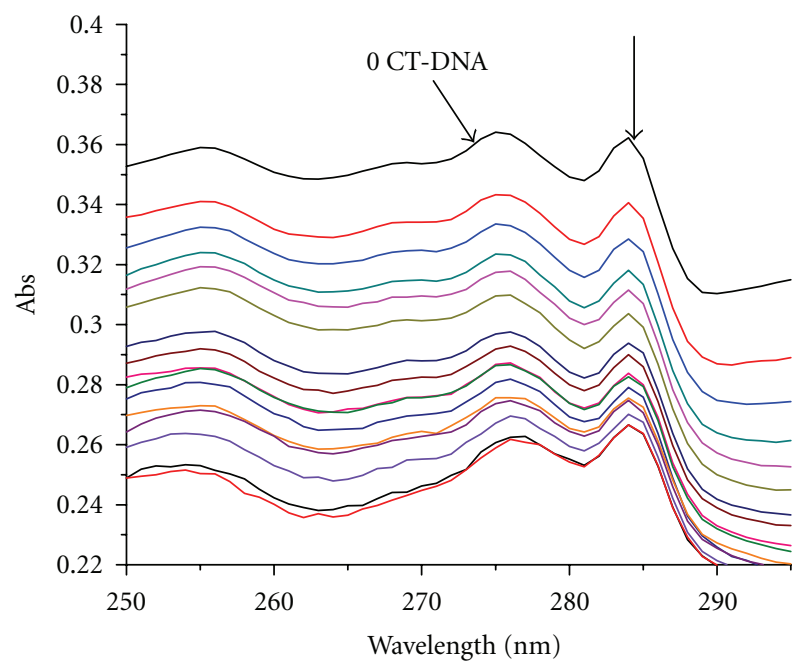

(a)

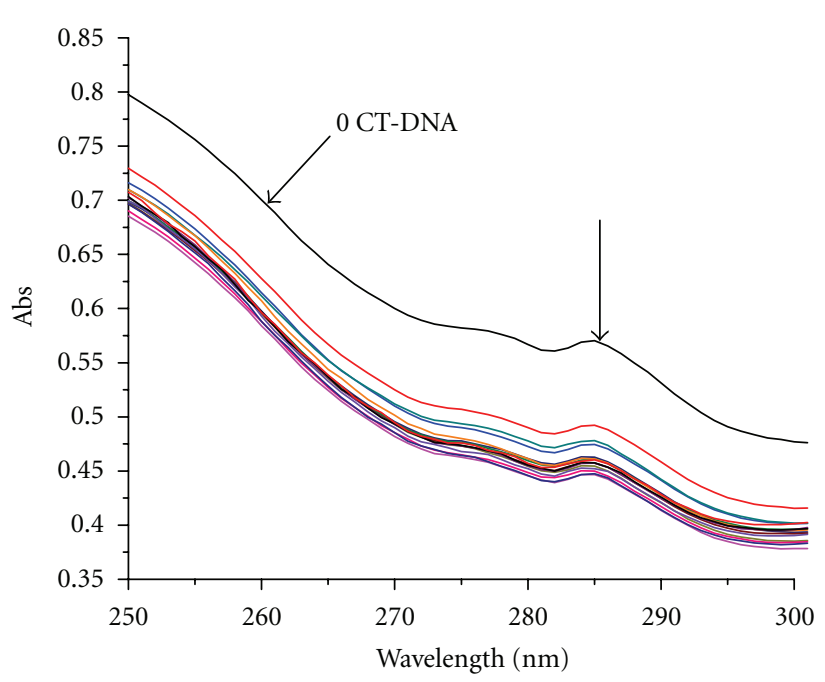

(c)

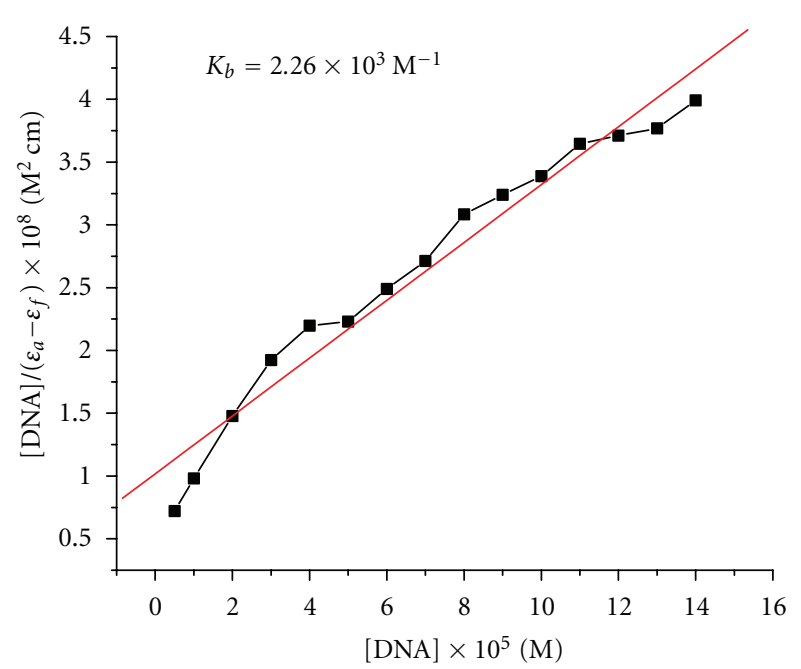

(b)

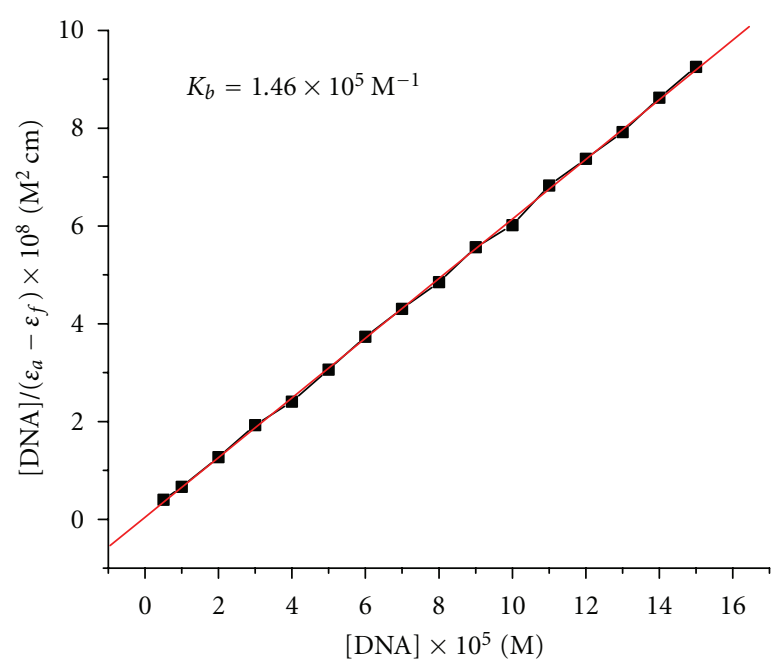

(d)

Figure 2: Absorption spectra of the ligand babb (a), Cd (II) complex (c) $\left(3 \times 10^{-5} \mathrm{~mol} \mathrm{~L}^{-1}\right)$ in the absence and presence of increasing amounts of DNA $\left(0-15 \times 10^{-5} \mathrm{~mol} \mathrm{~L}^{-1}\right)$ in $5 \mathrm{mmol} \mathrm{L}^{-1}$ Tris- $\mathrm{HCl} / 50 \mathrm{mmol} \mathrm{L}{ }^{-1} \mathrm{NaCl}$ buffer $(\mathrm{pH}=7.2)$. The arrow shows absorbance changes on increasing DNA concentration. Plot of $[\mathrm{DNA}] /\left(\varepsilon_{a}-\varepsilon_{f}\right)$ versus [DNA] for absorption titration of DNA with the ligand babb (b), Cd (II) complex (d).

quenching efficiency for each complex and determined by the classical Stern-Volmer equation [23]:

$$
\frac{I_{0}}{I}=1+K_{\mathrm{SV}}[Q] .
$$

$I_{0}$ and $I$ are the fluorescence intensities in the absence and presence of the quencher, respectively, and $[Q]$ is the concentration of the complex.

It was clear that the fluorescence intensity of EB-DNA system greatly decreases upon the addition of the complexes $(5 \mu \mathrm{L})$ gradually. The fluorescence quenching of EB-DNA by the complex is shown in Figure 3. The Stern-Volmer constant $K_{\mathrm{SV}}$ is obtained as the slope of $I_{0} / I$ versus complex linear plot. From Figure 3, the $K_{\mathrm{SV}}$ values for the ligand babb and $\mathrm{Cd}$ (II) complex are $1.44 \times 10^{4} \mathrm{M}^{-1}(R=0.98$ for 13 points) and $3.50 \times 10^{4} \mathrm{M}^{-1}(R=0.98$ for 7 points in the linear part), respectively. The results suggest that the ligand babb and Cd (II) complex can compete for DNA-binding sites with EB and displace EB from the EB-DNA system [42], which is usually characteristic of the intercalative interaction of compounds with DNA [43]. Additionally, The data suggest that the interaction of the Cd (II) complex with CT-DNA is stronger than that of the ligand babb, which is consistent with the above absorption spectral results.

3.5. Viscosity Measurement. Further clarification of the interactions between the Cd (II) complex and DNA was carried out by viscosity measurements. Due to its sensitivity to the change of length of DNA, viscosity measurement may be the most effective means to study the binding mode of 


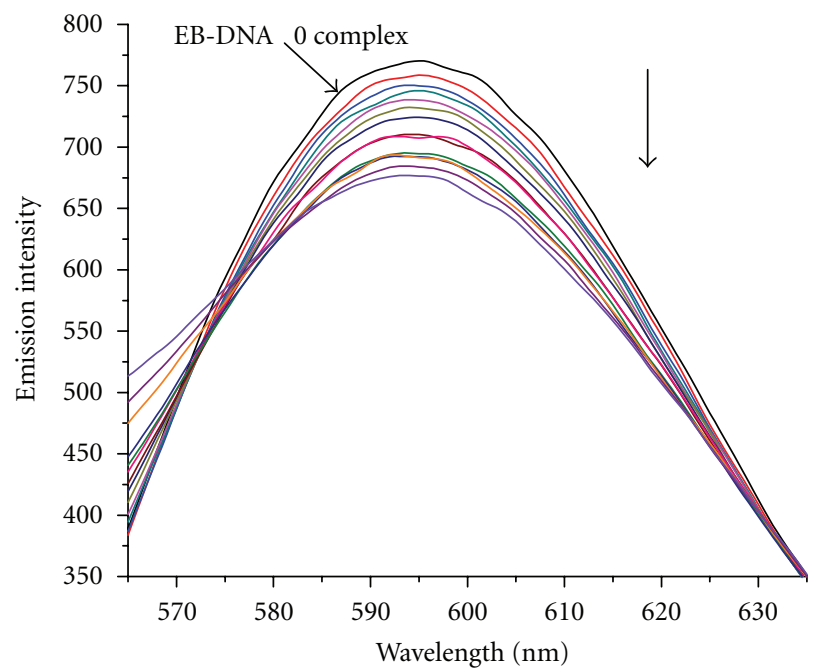

(a)

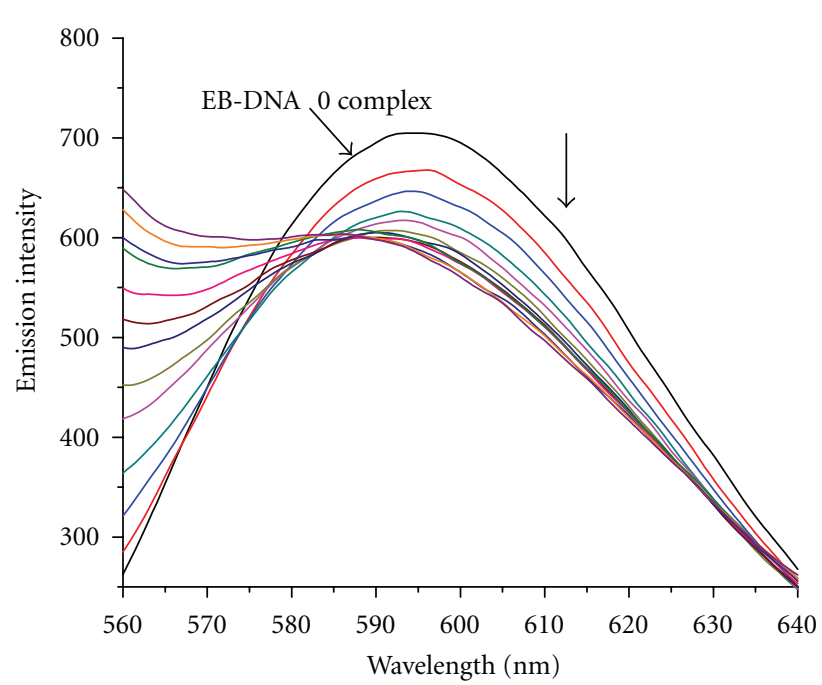

(c)

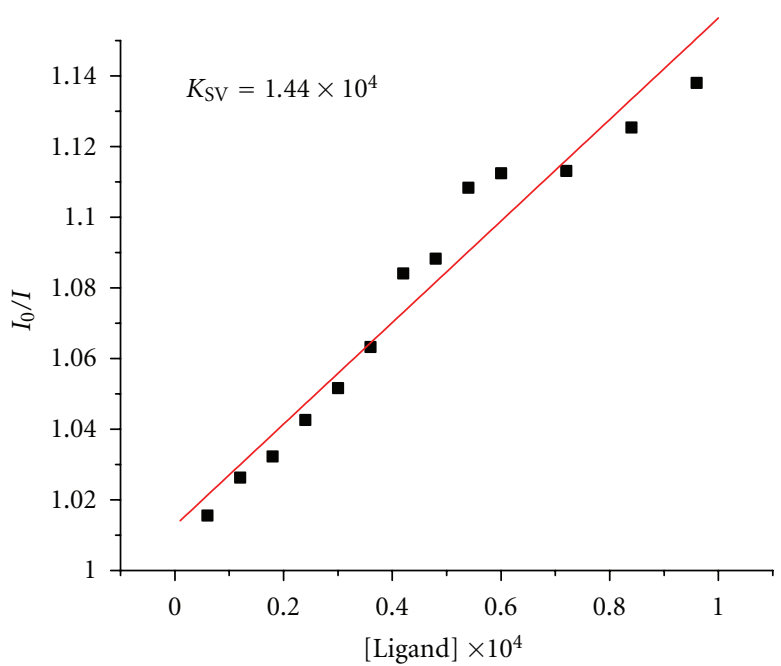

(b)

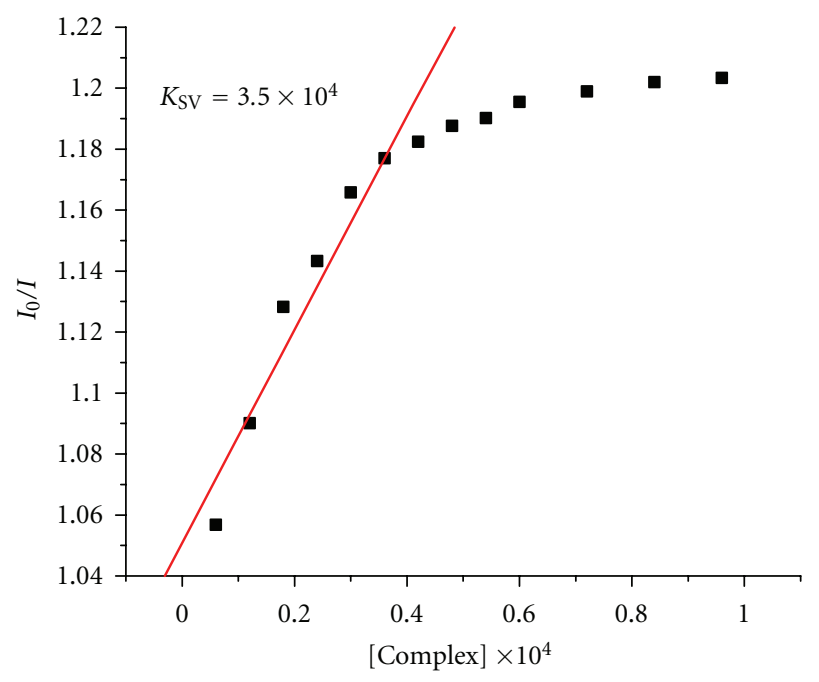

(d)

FIgURE 3: Emission spectra of EB bound to CT-DNA in the presence of the ligand babb (a), Cd (II) complex (c), [Complex] = $3 \times 10^{-5} \mathrm{M}$; $\lambda_{\mathrm{ex}}=520 \mathrm{~nm}$. The arrows show the intensity changes upon increasing concentrations of the complex. Fluorescence quenching curves of EB bound to CT-DNA by the ligand babb (b), Cd (II) complex (d). (Plots of $I_{0} / I$ versus [Complex].)

complex to DNA [22]. A significant increase in the viscosity of DNA on the addition of the compounds indicates the intercalative mode of binding to DNA. In contrast, complex that binds in the DNA grooves by partial and/or nonclassical intercalation causes less pronounced (positive or negative) or no change in DNA solution viscosity [40]. Titrations were performed for the compounds $(3-35 \mu \mathrm{M})$, and the complex was introduced into the CT-DNA solution $(50 \mu \mathrm{M})$ present in the viscometer. Viscosity values were calculated from the observed flow time of CT-DNA containing solutions corrected from the flow time of buffer alone $\left(t_{0}\right), \eta=$ $\left(t-t_{0}\right) / t_{0}[44]$. Data were presented as $\left(\eta / \eta_{0}\right)^{1 / 3}$ versus the ratio of the concentration of the complex to CT-DNA, where $\eta$ is the viscosity of CT-DNA in the presence of the complex and $\eta_{0}$ is the viscosity of CT-DNA alone. Viscosity measurements were carried out on CT-DNA by varying the concentration of the compound. Figure 4 shows the ligand babb and Cd (II) complex cause increase in the relative viscosity of DNA. This may be explained by the fact that they both can intercalate the adjacent DNA base pairs, leading to an increase in the separation of base pairs at intercalation sites and, thus, an increase in overall DNA contour length. So the results demonstrate that the complex could bind to DNA by intercalation mode, which is consistent with the above absorption and fluorescence spectral results.

\section{Conclusions}

In this paper, a new ligand babb and its Cd (II) complex have been synthesized and characterized. The DNA-binding 


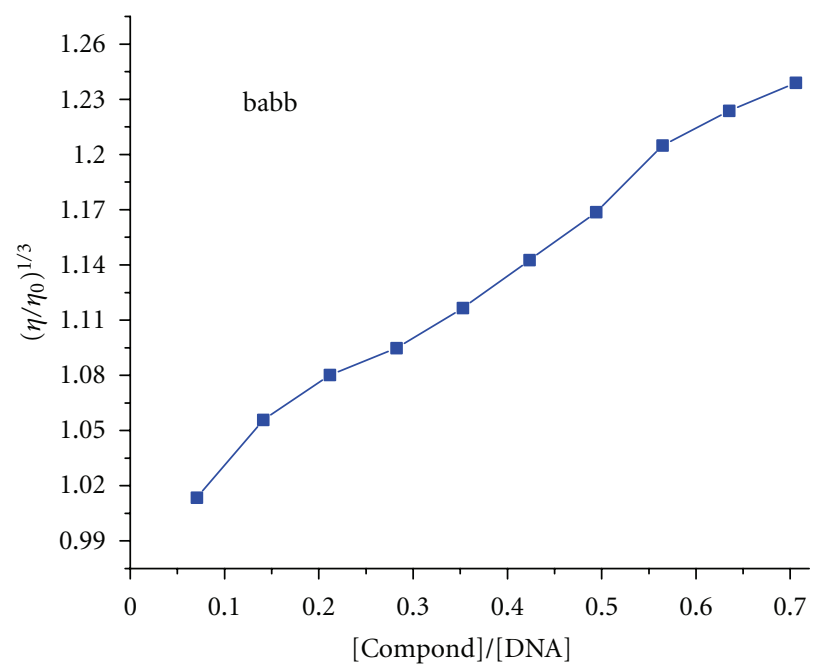

(a)

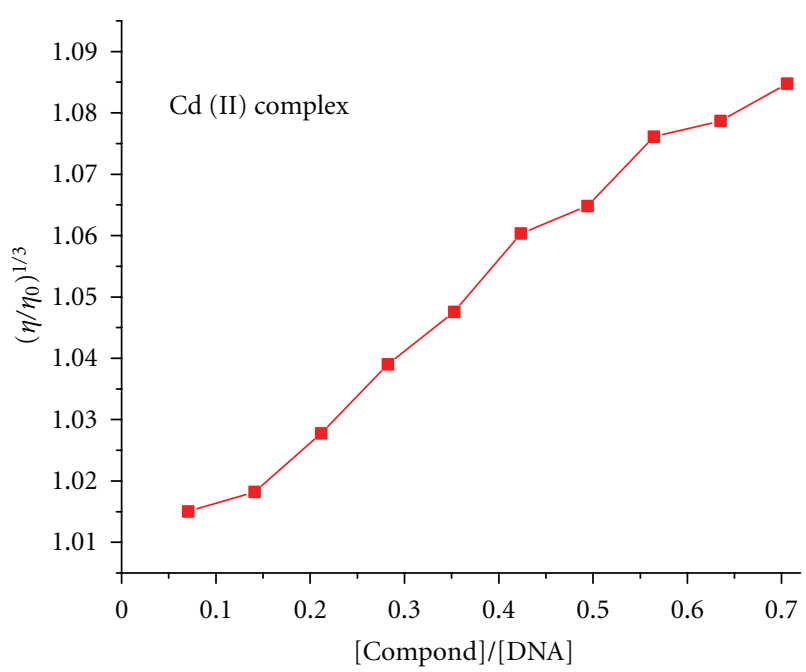

(b)

FIGURE 4: Effect of increasing amounts of the ligand babb (a), Cd (II) complex (b) on the relative viscosity of CT-DNA at $25( \pm 0.1)^{\circ} \mathrm{C}$ in $5 \mathrm{mmol} \mathrm{L}^{-1}$ Tris- $\mathrm{HCl}$ buffer $\left(\mathrm{pH}=7.2\right.$, [DNA] $\left.=5 \times 10^{-5} \mathrm{M}\right)$.

properties of the ligand babb and Cd (II) complex were investigated by electronic absorption, fluorescence, and viscosity measurements. The results indicate that they both can bond to CT-DNA in an intercalation mode and the Cd (II) complex shows higher affinity than the free ligand, which can be attributed to the more planar structure owing to upon coordination to the metal. The results can provide the evidence for designing the drugs and pharmaceuticals on a molecular level and warrant further in vivo experiments and pharmacological assays.

\section{Supporting Information}

Crystallographic data (excluding structure factors) for the structure in this paper have been deposited with the Cambridge Crystallographic Data Centre as supplementary publication CCDC 826633. Copies of the data can be obtained, free of charge, on application to the CCDC, 12 Union Road, Cambridge CB2 1EZ, UK. Tel: +44-01223-762910; fax: +44-01223-336033; e-mail: deposit@ccdc.cam.ac.uk or http://www.ccdc.cam.ac.uk/.

\section{Acknowledgments}

The authors acknowledge the financial support and grant from "Qing Lan" Talent Engineering Funds by Lanzhou Jiaotong University. The grant from "Long Yuan Qing Nian" of Gansu Province also is acknowledged.

\section{References}

[1] J. Reedijk, Comprehensive Coordination Chemistry, vol. 2, Chapter 13.2, Pergamon, Oxford, UK, 1987.

[2] D. A. Horton, G. T. Bourne, and M. L. Smythe, "The combinatorial synthesis of bicyclic privileged structures or privileged substructures," Chemical Reviews, vol. 103, no. 3, pp. 893-931, 2003.

[3] E. Lukevics, P. Arsenyan, I. Shestakova, I. Domracheva, A. Nesterova, and O. Pudova, "Synthesis and antitumour activity of trimethylsilylpropyl substituted benzimidazoles," European Journal of Medicinal Chemistry, vol. 36, no. 6, pp. 507-515, 2001.

[4] L. Garuti, M. Roberti, and E. De Clercq, "Synthesis and antiviral/antiproliferative activity of some N-sulphonylbenzimidazoles," Bioorganic \& Medicinal Chemistry Letters, vol. 12, no. 19, pp. 2707-2710, 2002.

[5] A. Gellis, H. Kovacic, N. Boufatah, and P. Vanelle, "Synthesis and cytotoxicity evaluation of some benzimidazole-4,7-diones as bioreductive anticancer agents," European Journal of Medicinal Chemistry, vol. 43, no. 9, pp. 1858-1864, 2008.

[6] Ö.Ö Guven, T. Erdogan, H. Goker, and S. Yildiz, "Synthesis and antimicrobial activity of some novel phenyl and benzimidazole substituted benzyl ethers," Bioorganic \& Medicinal Chemistry Letters, vol. 17, no. 8, pp. 2233-2236, 2007.

[7] K. Kopanska, A. Najda, J. Zebrowska et al., "Synthesis and activity of $1 \mathrm{H}$-benzimidazole and $1 \mathrm{H}$-benzotriazole derivatives as inhibitors of Acanthamoeba castellanii," Bioorganic and Medicinal Chemistry, vol. 12, no. 10, pp. 2617-2624, 2004.

[8] S. M. Sondhi, S. Rajvanshi, M. Johar, N. Bharti, A. Azam, and A. K. Singh, "Anti-inflammatory, analgesic and antiamoebic activity evaluation of pyrimido[1,6-a]benzimidazole derivatives synthesized by the reaction of ketoisothiocyanates with mono and diamines," European Journal of Medicinal Chemistry, vol. 37, no. 10, pp. 835-843, 2002.

[9] M. Mrksich and P. B. Dervan, "Enhanced sequence specific recognition in the minor groove of DNA by covalent peptide dimers: Bis(pyridine-2-carboxamidonetropsin) $(\mathrm{CH} 2) 3$ 6," Journal of the American Chemical Society, vol. 115, no. 22, pp. 9892-9899, 1993.

[10] C. Kokubo and T. Katsuki, "Highly enantioselective catalytic oxidation of alkyl aryl sulfides using Mn-salen catalyst," Tetrahedron, vol. 52, no. 44, pp. 13895-13900, 1996.

[11] S. Schoumacker, O. Hamelin, J. Pécaut, and M. Fontecave, "Catalytic asymmetric sulfoxidation by chiral manganese 
complexes: acetylacetonate anions as chirality switches," Inorganic Chemistry, vol. 42, no. 24, pp. 8110-8116, 2003.

[12] C. M. Dupureur and J. K. Barton, "Structural studies of $\Lambda$ and $\Delta-[\operatorname{Ru}(\text { phen }) 2 \mathrm{dppz}]^{2+}$ bound to d(GTCGAC) $)_{2}$ : characterization of enantioselective intercalation," Inorganic Chemistry, vol. 36, no. 1, pp. 33-43, 1997.

[13] M. S. Diaz-Cruz, J. Mendieta, A. Monjonelli, R. Tauler, and M. Esteban, "Study of the znic-binding properties of glutathione by differential pulse polarography and multivariate curve resolution," Journal of Inorganic Biochemistry, vol. 70, no. 1-2, pp. 9-98, 1988.

[14] H. L. Wu, X. C. Huang, J. K. Yuan et al., "A V-shaped ligand 2,6-bis(2-benzimidazolyl)pyridine and its picrate $\mathrm{Mn}$ (II) complex: synthesis, crystal structure and DNA-binding properties," European Journal of Medicinal Chemistry, vol. 45, no. 11, pp. 5324-5330, 2010.

[15] H. L. Wu, K. Li, T. Sun et al., "Synthesis, structure, and DNAbinding properties of manganese(II) and zinc(II) complexes with tris (N-methylbenzimidazol-2-ylmethyl)amine ligand," Transition Metal Chemistry, vol. 36, pp. 21-28, 2011.

[16] H. L Wu, R. R. Yun, K. Wang, K. T. Li, X. C. Huang, and T. Sun, "Synthesis, crystal structure, and spectrum properties of cobalt(II) complexes based on tridentate 1,3Bis(benzimidazol-2-yl)-2-oxopropane ligand and derivative," Zeitschrift für Anorganische und Allgemeine Chemie, vol. 636, no. 3-4, pp. 629-633, 2010.

[17] H. L. Wu, X. C. Huang, J. L. Yuan et al., "Synthesis, Crystal Structure and DNA-binding Properties of a Nickel(II) Complex with 2, 6-Bis(2-benzimidazolyl)pyridine," Zeitschrift für Naturforschung, vol. 65, no. 11, pp. 1334-1340, 2010.

[18] J. B. Chaires, "Tris(phenanthroline)ruthenium(II) enantiomer interactions with DNA: mode and specificity of binding," Biochemistry, vol. 32, no. 10, pp. 2573-2584, 1993.

[19] M. E. Reichmann, S. A. Rice, C. A. Thomas, and P. Doty, "A further examination of the molecular weight and size of desoxypentose nucleic acid," Journal of the American Chemical Society, vol. 76, no. 11, pp. 3047-3054, 1954.

[20] A. M. Pyle, J. P. Rehmann, R. Meshoyrer, C. V. Kumar, N. J. Turro, and J. K. Barton, "Mixed-ligand complexes of ruthenium(II): factors governing binding to DNA," Journal of the American Chemical Society, vol. 111, no. 8, pp. 3051-3058, 1989.

[21] A. Wolfe, G. H. Shimer, and T. Meehan, "Polycyclic aromatic hydrocarbons physically intercalate into duplex regions of denatured DNA," Biochemistry, vol. 26, no. 20, pp. 6392-6396, 1987.

[22] B. C. Baguley and M. Le Bret, "Quenching of DNA-ethidium fluorescence by amsacrine and other antitumor agents: a possible electron-transfer effect," Biochemistry, vol. 23, no. 5, pp. 937-943, 1984.

[23] J. R. Lakowicz and G. Weber, "Quenching of fluorescence by oxygen. Probe for structural fluctuations in macromolecules," Biochemistry, vol. 12, no. 21, pp. 4161-4170, 1973.

[24] C. Tan, J. Liu, L. Chen, S. Shi, and L. Ji, "Synthesis, structural characteristics, DNA binding properties and cytotoxicity studies of a series of $\mathrm{Ru}(\mathrm{III})$ complexes," Journal of Inorganic Biochemistry, vol. 102, no. 8, pp. 1644-1653, 2008.

[25] K. Takahashi, Y. Nishida, and S. Kida, "Crystal structure of copper(II) complex with N,N-bis(2-benzimidazolylmethyl)benzylamine," Polyhedron, vol. 3, no. 1, pp. 113-116, 1984.

[26] H. L. Wu, R. R. Yun, K. Li, K. T. Wang, X. C. Huang, and T. Sun, "Synthesis, crystal structure and spectra properties of the nickel (II) complex with 1,3-bis(1-benzylbenzimidazol2-yl)2-oxopropane," Synthesis and Reactivity in Inorganic, MetalOrganic and Nano-Metal Chemistry, vol. 39, no. 9, pp. 614617, 2009.

[27] Bruker, APEX2 and SAINT, Bruker AXS, Madison, Wash, USA, 2007.

[28] G.M. Sheldrick, SHELXTL, Siemmens Analytical X-Ray Instruments, Madison, Wash, USA, 1996.

[29] W. J. Geary, "The use of conductivity measurements in organic solvents for the characterisation of coordination compounds," Coordination Chemistry Reviews, vol. 7, no. 1, pp. 81-122, 1971.

[30] J. P. Collin, I. M. Dixon, J. P. Sauvage, J. A. G. Williams, F. Barigelletti, and L. Flamigni, "Synthesis and photophysical properties of iridium(III) bisterpyridine and its homologues: a family of complexes with a long-lived excited state," Journal of the American Chemical Society, vol. 121, no. 21, pp. 50095016, 1999.

[31] C. Y. Su, B. S. Kang, C. X. Du, Q. C. Yang, and T. C. W. Mak, "W. Formation of mono-, bi-, tri-, and tetranuclear $\mathrm{Ag}(\mathrm{I})$ complexes of C3-symmetric tripodal benzimidazole ligands," Inorganic Chemistry, vol. 39, no. 21, pp. 4843-4849, 2000.

[32] T. J. Lane, I. Nakagawa, J. L. Walter, and A. J. Kandathil, "Infrared investigationof certain imidazole derivatives and their metal chelates," Inorganic Chemistry, vol. 1, no. 1, pp. 267-276, 1962.

[33] J. S. Richard and R. B. Martin, "Interactions of histidine and other imidazole derivatives with transition metal ions in chemical and biological systems," Chemical Reviews, vol. 74, no. 4, pp. 471-517, 1974.

[34] T. Fonseca, B. Gigante, and T. L. Gilchrist, "A short synthesis of phenanthro[2,3-d]imidazoles from dehydroabietic acid. Application of the methodology as a convenient route to benzimidazoles," Tetrahedron, vol. 57, no. 9, pp. 1793-1799, 2001.

[35] H. L. Wu, K. T. Wang, R. R. Yun, X. C. Huang, K. Li, and T. Sun, "Studies on copper(II), cobalt (II) and nickel (II) picrate complexes with the ligand 1,3-Bis(2-benzimidazyl)2-thiapropane," Synthesis and Reactivity in Inorganic, MetalOrganic and Nano-Metal Chemistry, vol. 39, no. 10, pp. 629632, 2009.

[36] Z. X. Su, Y. Q. Wan, and H. L. Wu, "Synthesis, crystal structure and cyclic voltammetry of a copper (II) complex with tripod ligand tris(2-benzimidazolylmethyl)amine," Synthesis and Reactivity in Inorganic, Metal-Organic and Nano-Metal Chemistry, vol. 35, no. 7, pp. 553-558, 2005.

[37] M. Baldini, M. Belicchi-Ferrari, F. Bisceglie et al., "Copper(II) complexes with substituted thiosemicarbazones of $\alpha$ ketoglutaric acid: synthesis, X-ray structures, DNA binding studies, and nuclease and biological activity," Inorganic Chemistry, vol. 43, no. 22, pp. 7170-7179, 2004.

[38] J. K. Barton, A. T. Danishefsky, and J. M. Goldberg, "Tris(phenanthroline)ruthenium(II): stereoselectivity in binding to DNA," Journal of the American Chemical Society, vol. 106, no. 7, pp. 2172-2176, 1984.

[39] S. A. Tysoe, R. J. Morgan, A. D. Baker, and T. C. Strekas, "Pyrene excimer formation in individual oil droplets dispersed in gelatin matrixes: space- and time-resolved fluorescence spectroscopy," The Journal of Physical Chemistry, vol. 97, no. 8, pp. 1707-1711, 1993.

[40] T. M. Kelly, A. B. Tossi, D. J. Connell, and T. C. Strekas, "A study of the interactions of some polypyridylruthenium(LI) complexes with DNA using fluorescence 
spectroscopy, topoisomerisatlon and thermal denaturalkm," Nucleic Acids Research, vol. 13, no. 17, pp. 6017-6034, 1985.

[41] Q. Wang, Z. Y. Yang, G. F. Qi, and D. D. Qin, "Synthesis, crystal structure, antioxidant activities and DNA-binding studies of the $\operatorname{Ln}(\mathrm{III})$ complexes with 7-methoxychromone3-carbaldehyde-(4'-hydroxy) benzoyl hydrazone," European Journal of Medicinal Chemistry, vol. 44, no. 6, pp. 2425-2433, 2009.

[42] Y. B. Zeng, N. Yang, W. S. Liu, and N. Tang, "Synthesis, characterization and DNA-binding properties of La(III) complex of chrysin," Journal of Inorganic Biochemistry, vol. 97, no. 3, pp. 258-264, 2003.

[43] V. K. Challa, K. B. Jacqueline, and J. T. Nicholas, "Photophysics of ruthenium complexes bound to double helical DNA," Journal of the American Chemical Society, vol. 107, no. 19, pp. 5518-5523, 1985.

[44] T. C. Michael, R. Marisol, and J. B. Allen, "Voltammetric studies of the interaction of metal chelates with DNA. 2. Tris-chelated complexes of cobalt(III) and iron(II) with 1,10phenanthroline and 2,2'-bipyridine," Journal of the American Chemical Society, vol. 111, no. 24, pp. 8912-8914, 1989. 


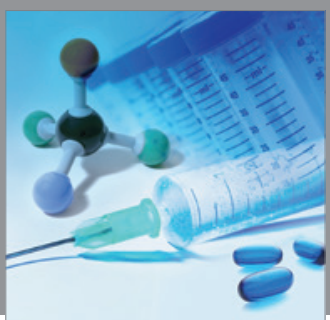

International Journal of

Medicinal Chemistry

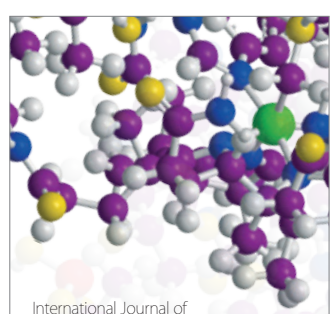

Carbohydrate Chemistry

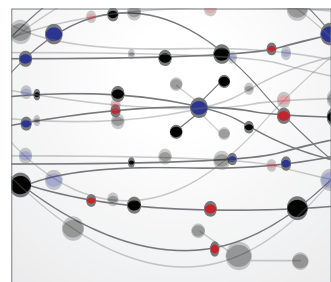

The Scientific World Journal
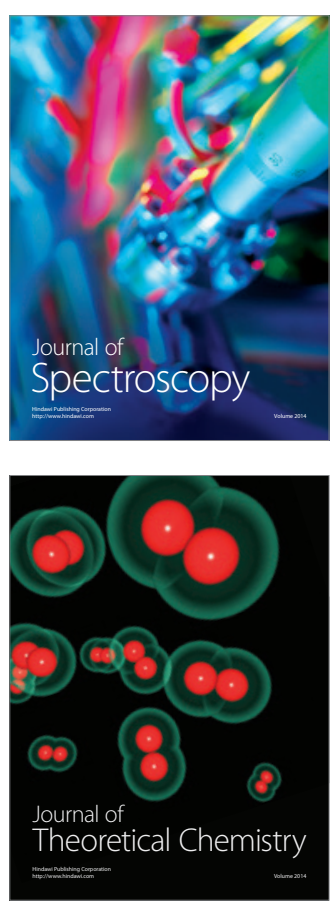
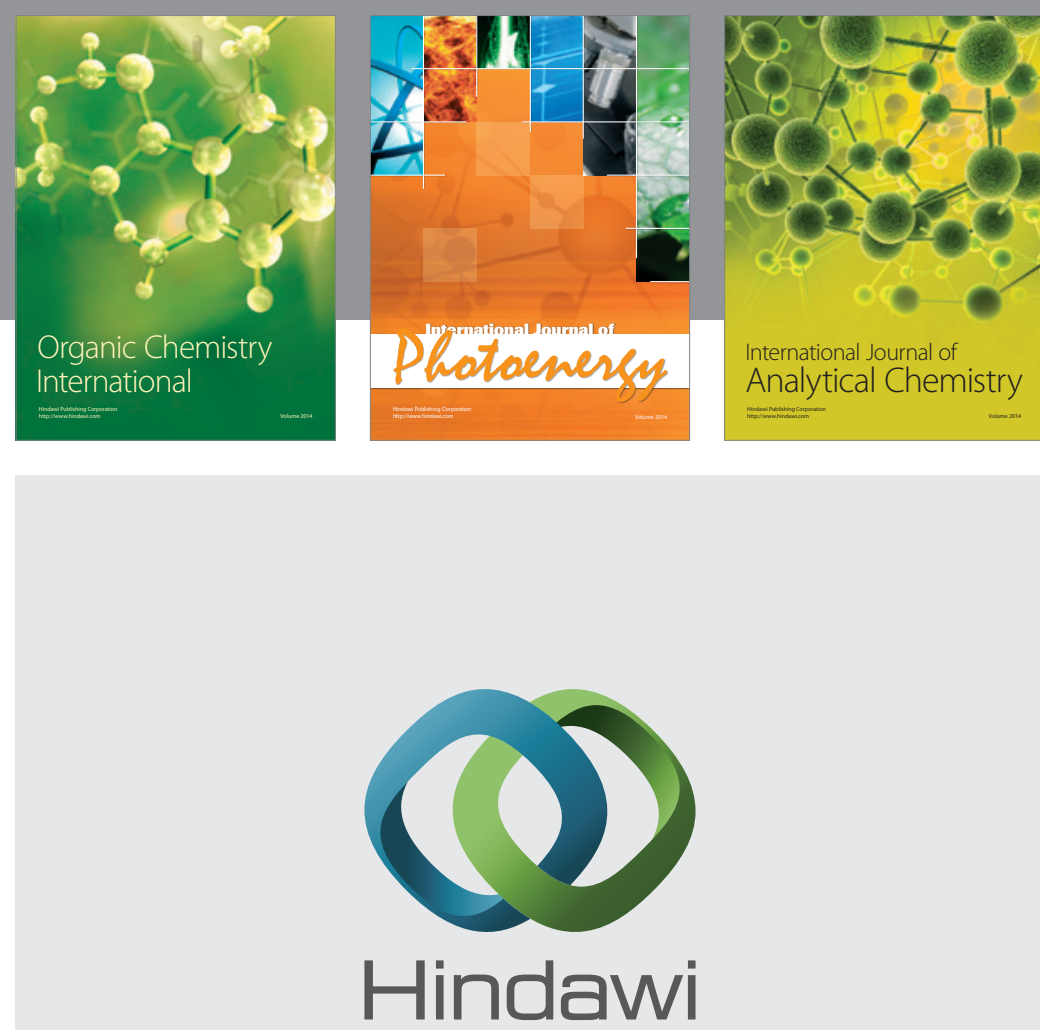

Submit your manuscripts at

http://www.hindawi.com
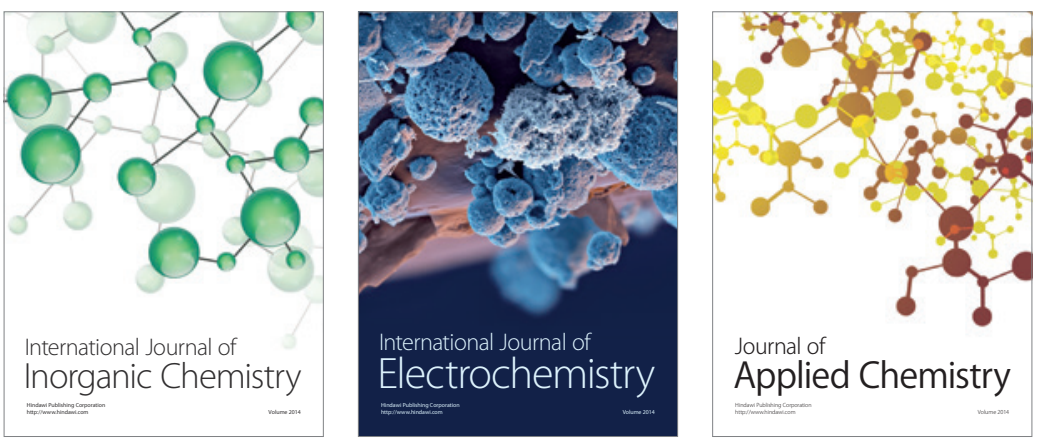

Journal of

Applied Chemistry
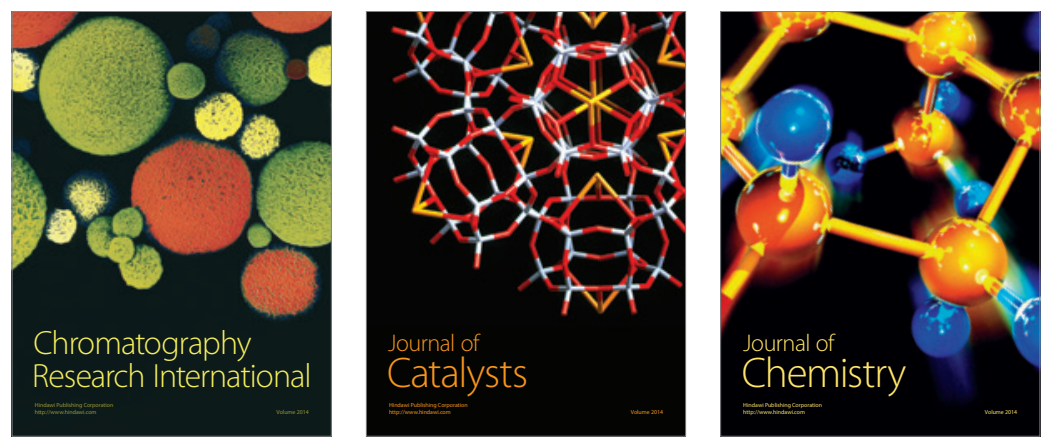
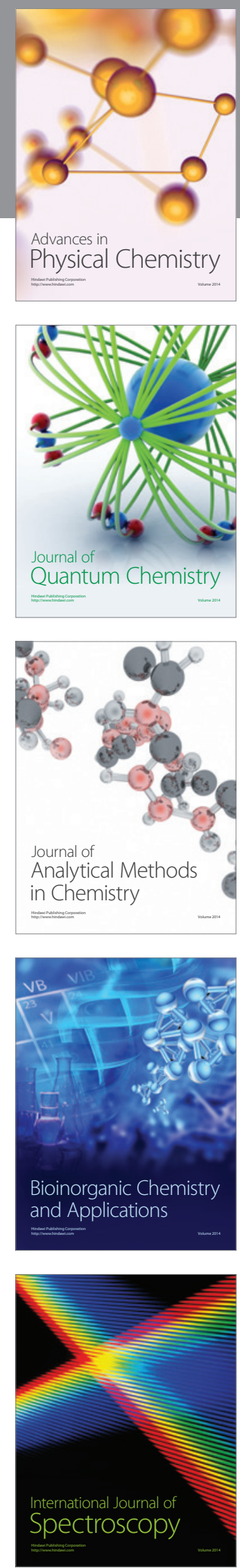